\title{
Xanthogranulomatous oophoritis: a rare chronic inflammatory non- neoplastic ovarian pseudotumor
}

\author{
Saswati Tripathy*, Santhamani P. M.
}

Department of Obstetrics and Gynaecology, SRM MCH and RC, SRM University, Tamilnadu, India

Received: 03 August 2016

Accepted: 02 September 2016

\section{*Correspondence:}

Dr. Saswati Tripathy,

E-mail: saswatitripathy@yahoo.com

Copyright: $\odot$ the author(s), publisher and licensee Medip Academy. This is an open-access article distributed under the terms of the Creative Commons Attribution Non-Commercial License, which permits unrestricted non-commercial use, distribution, and reproduction in any medium, provided the original work is properly cited.

\begin{abstract}
Xanthogranulomatous inflammation is a form of chronic inflammation which is destructive to the affected organ and is characterized by clustering of foamy macrophages among other inflammatory cells. It is mostly localized to the kidney, renal pelvis and uncommonly found in organs like ovary and fallopian tube. Very few cases of xanthogranulomatous oophoritis have been reported till date. Along with its rarity, this pseudotumor may be confused with ovarian neoplasm and tuberculosis. Here we report a 45 year old female who presented clinically and radiologically with suspicion of malignancy. The histopathological analysis revealed it as xanthogranulomaotus oophoritis.
\end{abstract}

Keywords: Xanthogranulomatous, Oophoritis, Histiocytes

\section{INTRODUCTION}

Xanthogranulomatous inflammation is a form of chronic inflammation which is destructive in nature. It destroys the tissue of the affected organ. This is an uncommon process mostly affecting the kidney. But other organs in which xanthogranulomaotus inflammation have been reported are stomach, anorectal area, bone, urinary bladder, testes, epididymis, vagina and endometrium.

Xanthogranulomatous inflammation of female genital tract is a rare occurrence. The involvement of endometrium, fallopian tubes or ovaries can clinically present with mass in the pelvic cavity which can be misdiagnosed as ovarian neoplasm and tuberculosis. ${ }^{1}$

The clinical presentation, radiological and macroscopic features of xanthogranulomatous oophoritis may mimic as ovarian tumour. ${ }^{1,2}$ Here we present a case of xanthogranulomatous oophoritis in a 45 year old female who was clinically and radiologically misdiagnosed as ovarian neoplasm. Histopathological examination revealed the characteristic features of xantho-granulomatous oophoritis.

\section{CASE REPORT}

A 45 year old female presented to the gynaecology outpatient department with complaints of lower abdominal pain since past 20 days, intermittent fever and dysuria since 10 days. She had eight months of secondary amenorrhoea and her previous menstrual cycles were regular. She had two children, sterilised and her last child birth was 28 years back.

She was a known diabetic on treatment with oral hypoglycaemic drugs for past three years. There was no suggestive past or family history of any disease. On physical examination, the patient was febrile and was mildly anemic but had pallor. The cardiovascular and respiratory system examination was normal. The abdominal examination revealed a mass of twenty weeks with mild tenderness. Speculum examination revealed a healthy cervix and vagina. Vaginal examination 
confirmed mass of twenty weeks and fornices were free. Her routine haematological examinations were within normal limits. All investigations for pyrexia were done which revealed neutrophilic leucocytosis and ESR of 66 $\mathrm{mm}$. The malaria test and montoux test were negative. The urine culture showed moderate growth of E.coli and Kleibsillae which were sensitive to amikacin and imipenem. The pelvic ultrasonography showed normal size uterus $(9.2 \times 4.8 \times 5.4 \mathrm{~cm})$ and left ovary $(2.8 \times 2.4$ $\mathrm{cm})$. There was a well-defined solid cystic lesion of size $(14 \times 7 \mathrm{~cm})$ in the right adenexal region. The mass was seen containing echogenic strands, air shadows and solid areas with vascularity. There was no evidence of calcification. The final ultrasound impression was being? Right adenexal mass/? Bowel mass. The patient was subjected to CT scan which revealed a mass of $19 \mathrm{x} 14 \mathrm{x}$ 14 size of mixed density with abdominopelvic extension towards right side. The lesion showed cystic component with thick rim having peripheral rim enhancement. Specks of calcification were seen within the solid component. The X-ray KUB showed soft tissue dense opacity in the region of bladder and more towards right side. The tests for tumour marker like CEA, CA-125 were within normal limit. Based on the above findings, a provisional diagnosis of malignant ovarian neoplasm was made. Laparotomy findings revealed a uterus of size six weeks and a right ovarian abscess of size $15 \times 10 \mathrm{~cm}$. The pus was drained out and sent for culture. Bowel was densely adherent to the mass. Left side hydrosalpinx was present. Adhesions were released from the cyst wall. Laparotomy was preceded to total abdominal hysterectomy with bilateral salpingo oophorectomy (Figure 1).

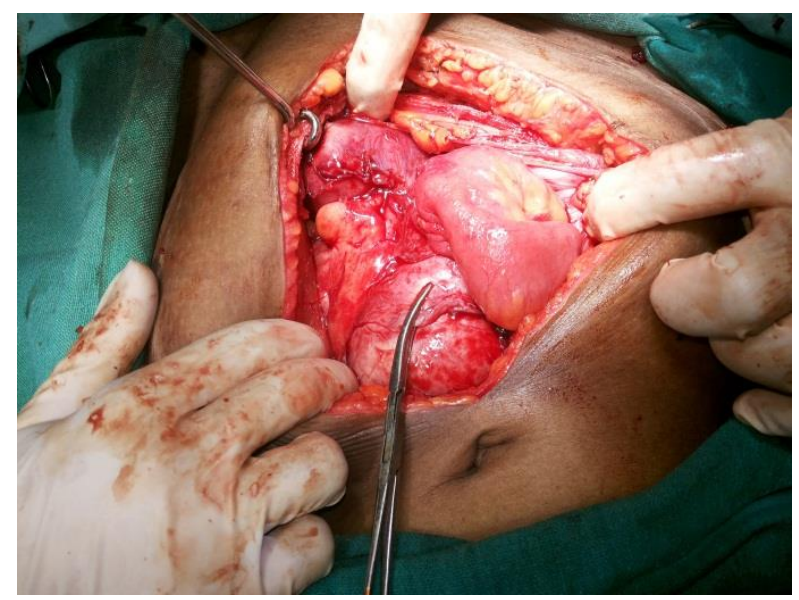

Figure 1: Laparotomy showing the ovarian mass.

A specimen and pus was subjected for histopathological examination. As shown in Figure 2, the microscopic examination of specimen revealed dense infiltration ovarian tissue by plasma cells arranged in diffused sheet like pattern admixed with clusters of histiocytes and a few multi nucleated giant cells. Histiocytes showed presence of pinkish eosinophilic debris within the cytoplasm. Based on these findings a diagnosis of xanthogranulomatous inflammation of the right ovary with abscess was made. Zeihl-Nelson stain of both specimen and pus was negative for acid fast bacilli. The post-operative recovery of the patient was uneventful and the patient was discharged on $8^{\text {th }}$ day.

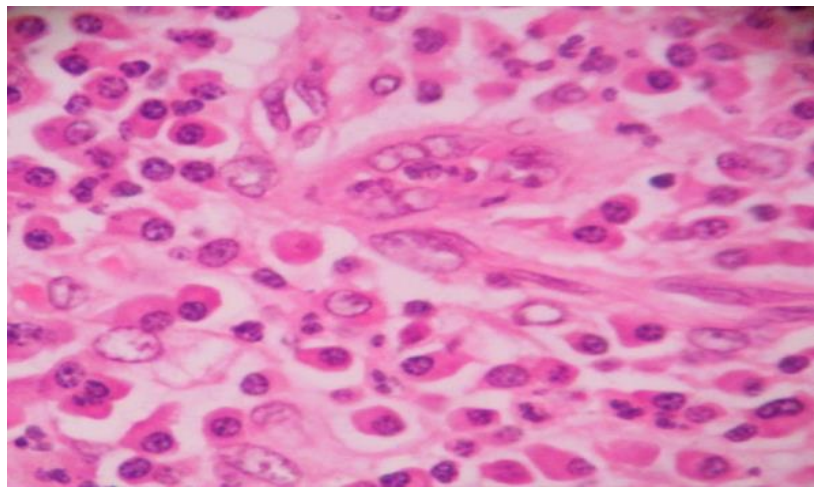

Figure 2: Photomicrograph of histopathological specimen shows abundant foamy histiocytes admixed with acute inflammatory cells. (H and $\mathrm{E}, 40 x)$.

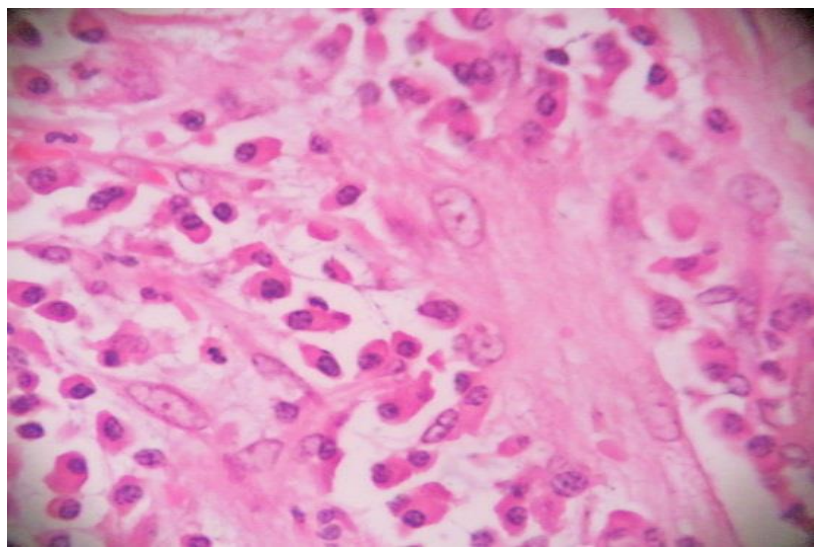

Figure 3: Photomicrograph of histopathological specimen shows abundant foamy histiocytes admixed with chronic inflammatory cells. (H and E, 40x).

\section{DISCUSSION}

Xanthogranulomatous inflammation is a special type of chronic inflammation with destruction of the tissues of the affected organs. Most common organs affected are kidney and gall bladder. But other organs affected by this inflammation are stomach, anorectal area, bone, urinary bladder, testes etc. This type of inflammation involving female genital tract is very rare condition and is confined to mostly endometrium. Involvement of vagina, cervix, fallopian tube and ovary has been documented. ${ }^{3}$ Very few cases of xanthogranulomatous oophoritis have been reported from India. The etiopathogenesis of xanthogranulomatous oophoritis is not clear. Many theories have been proposed, such as theory of infection, leomyoma, endometriosis, use of IUCD, inefficient or inappropriate drugs (antibiotics) etc. ${ }^{4}$ The theory of infection is supported by the clinical evidence of infection and growth of bacteria such as Escherichia coli, Bacteroides fragilis, Proteus vulgaris, and Salmonella 
typhi from the affected tissue. The clinical manifestation, imaging detection and macroscopic observation of xanthogranulomatous oophoritis are subject to be confused with ovarian malignancy. Most of the cases of xanthogranulomatous oophoritis are misdiagnosed as ovarian cancers. The clinical presentations include fever, abdominal mass, and pain in the abdomen, menorrhagia, anemia etc. Gynecological examination reveals adnexal mass, tenderness along with lab findings like elevated ESR and raised white blood cell count. Radiological findings may simulate malignant ovarian neoplasm. In gross examination of the affected ovary, it is found to be enlarged with size varies from 3-7 cm. It looks solid, yellow, nodular mass which occasionally becomes cystic due to liquefactive necrosis. The inflammation may extend beyond the ovary and involve the neighbouring pelvic peritoneum resulting in adhesion. So these features may arouse the suspicion of malignancy. On gross examination there is proliferation of foamy histiocytes and fibrous organization of the chronic inflammatory process.

Differential diagnosis of xanthogranulomatous oophoritis may be non- neoplastic or neoplastic. The non-neoplastic conditions include infections like tuberculosis, fungal infections which can be ruled out by culture and special stains. In malakoplakia, the cytoplasmic concentric calcific bodies (Michaelis Guttmann bodies) are found. Malakoplakia occurs mainly in the urinary system, but xanthogranulomatous inflammation occurs in the genital system. Neoplastic conditions include lymphoma or leukaemia, malignant small cell tumour and sclerosing stromal tumour may come under the differential diagnosis. Treatment of choice for xanthograulomatous oophoritis is oophorectomy. In this case we performed a total abdominal hysterectomy with bilateral salpingo oophorectomy. But a preoperative diagnosis should be considered to avoid radical surgical treatment. Patients with inflammatory diseases like PID, endometritis and IUCD users should be closely followed up because of their association with xanthogranulomatous oophoritis.

Funding: No funding sources

Conflict of interest: None declared

Ethical approval: Not Required

\section{REFERENCES}

1. Kalloli M, Bafna UD, Mukherjee G, Devi UK, Gurubasavangouda, Rathod PS. A rare xanthogranulomatous oophoritis presenting ovarian cancer. J Health Allied Sci. 2012;11(2):11.

2. Kumar MU, Potekar RM, Yelikar BR, Pande P. Xanthogranulomatous oophoritis-masquerading as ovarian neoplasm. Asian J Pharm Sci. 2012:2(2):308-9.

3. Kishore SH, Rajshri OP, Dravid NV. Xanthogranulomatous oophoritis mimicking as an ovarian neoplasm. J Case Reports. 2014;4(1):100-3.

4. Zhang XS, Dong HY, Zhang LL, Desouki MM, Zhao C. Xanthogranulomatous inflammation of the female genital tract report of three cases. J Cancer. 2012;3:100-6.

Cite this article as: Tripathy S, Santhamani PM. Xanthogranulomatous oophoritis: a rare chronic inflammatory non-neoplastic ovarian pseudotumor. Int J Reprod Contracept Obstet Gynecol 2016;5:3616-8. 